\title{
PRAKTIK SEKSUALITAS MENYIMPANG MASYARAKAT MUSLIM-MINANGKABAU: KAJIAN NEO-HISTORISISME TERHADAP FILM TITIAN SERAMBUT DIBELAH TUJUH
}

\author{
Dedi Arsa \\ Institut Agama Islam Negeri (LAIN) Bukittinggi, dediarsa@iainbukittinggiac.id

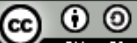 \\ (C)2020 by the authors. Submitted for possible open access publication under the terms and conditions \\ of the Creative Commons Attribution-ShareAlike 4.0 International License (CC-BY-SA) \\ license (https://creativecommons.org/licenses/by-sa/4.0/) \\ doi) DOI: http://dx.doi.org/10.30983/fuaduna.v4i2.3406
}

\begin{abstract}
This article discusses the practices of deviant sexuality in the Muslim-Minangkabau community depicted in early Indonesian films in relation to the socio-cultural context in the film as well as the socio-cultural context when the film was produced. The film in question is Titian Serambut Dibelah Tujuh by Asrul Sani. In this film some of the deviant practices of sexuality depicted are homosexuality, lesbianity, and bypersexuality (through the practice of rape). Using a neo-historicalism approach, which looks at the relation of literary texts (films) to their historical space and time, the narratives in this film relate to the context of their presence in the midst of Indonesian social reality and the setting of the film itself: this film exists as a critique of moral decadence The Old Order, which celebrates sexuality in public spaces and on the other hand, also describes the background society (which is also where the writer of the scenario came from) where the practices of sexuality diverged have their own traces in the history of this society.
\end{abstract}

Keywords: Sexuality; Flm; Muslim-Minangkabau.

\begin{abstract}
Abstrak
Artikel ini membahas praktik-praktik seksualitas menyimpang di tengah masyarakat Muslim-Minangkabau yang digambarkan dalam film Indonesia awal dalam relasinya dengan konteks sosial-budaya dalam film maupun konteks sosial-budaya ketika film ini diproduksi. Film yang dimaksud adalah Titian Serambut Dibelah Tujuh karya Asrul Sani. Dalam film ini beberapa praktik seksualitas menyimpang yang digambar adalah homoseksualitas, lesbianitas, dan hiperseksualitas (lewat praktik perkosaan). Dengan menggunakan pendekatan neo-historisisme, yang melihat relasi teks sastra (film) dengan ruang dan waktu historisnya, narasi-narasi dalam film ini terkait dengan konteks kehadirannya di tengah realitas sosial Indonesia dan latar filmnya itu sendiri: film ini hadir sebagai kritik atas dekadensi moral Orde Lama yang merayakan binalitas-seksualitas di ruang publik dan di sisi lain, juga menggambarkan masyarakat latar (yang juga dari mana si penulis skenarionya berasal) di mana praktik-praktik seksualitas menyimpang punya jejaknya tersendiri dalam sejarah puak ini.
\end{abstract}

Kata Kunci: Seksualitas; Film; Muslim-Minangkabau. 


\section{PENDAHULUAN}

Titian Serambut Dibelah Tujuh pernah difilmkan tahun 1950an. Difilmkan ulang pada 1982. Pada produksinya yang kedua ini, film ini diproduksi oleh Proyek Produksi Dewan Film Nasional dengan Chairul Umam sebagai sutradara. Mendapat pujian di berbagai suratkabar. Setahun setelahnya film ini memenangkan Piala Citra untuk kategori Skenario Asli Terbaik. ${ }^{1}$

Si penulis skenario adalah Asrul Sani, sastrawan dan sineas film ternama negeri ini, yang dikenal luas sebagai pelopor Angkatan '45. Bersama dua sastrawan lain, Chairil Anwar dan Rivai Apin, dia dianggap pembawa khazanah baru dalam dunia puisi dengan menulis Tiga Menguak Takdir. Rosihan Anwar ${ }^{2}$ yang menulis obituari di hari kematiannya menulis kalau dia adalah pribadi yang religius. Dia berasal dari utara Minangkabau, dari Rao. Dia pernah menjadi ketua lembaga kebudayaan milik NU (Nahdhatul Ulama), Lesbumi (Lembaga Seniman Budayawan Muslimin Indonesia). ${ }^{3}$

Ada beberapa tinjauan untuk film ini yang telah dikerjakan para peneliti terdahulu. Ada yang melihatnya dari sudut pandang religious-social movement, seperti yang dilakukan Ahmad Nuril Huda, dalam artikel "Negotiating Islam with cinema: A theoretical discussion on Indonesian Islamic films"; ${ }^{4}$ dan yang dilakukan Eric Sasono dalam tulisannya yang lain, "Islamic Revivalism

${ }^{1}$ Muhammad Arief, "Analisis Konteks Islam dan Budaya Minangkabau Dalam Skenario Film Titian Serambut Dibelah Tujuh"," Menara Ilmu X, No. 73 (2016): 213-216.

${ }^{2}$ Rosihan Anwar, "Asrul Sani Pribadi Religius," Republika, 2004; Biografi yang lebih ringkas lihat: Dendy Sugono, ed., "Ensiklopedia Sastra Indonesia Modern," in Pusat Bahasa (Jaka: Pusat Bahasa, 2003), 45-48.

${ }^{3}$ Di masa kemudian, juga menjadi Pengurus Pusat Nahdatul Ulama (NU). Lihat Sugono, "Ensiklopedia Sastra Indonesia Modern" Lihat Juga ; Korrie Layun Rampan, Leksikon Susastra Indonesia (Jakarta: Balai Pustaka, 2000) dan ; Ajip Rosidi, Mengenang Hidup Orang Lain: Sejumlah Obituari (Jakarta: Kepustakaan Populer Gramedia, 2010).

${ }^{4}$ Ahmad Nuril Huda, "Negotiating Islam with Cinema: A Theoretical Discussion on Indonesian Islamic Films, Wacana: Jurnal Ilmu Pengetahuan Budaya," 2012, 1 16. and Religious Piety in Indonesian Cinema" dalam T. P. Daniels (ed.), Performance, Popular Culture, and Piety in Muslim Southeast Asia. ${ }^{5}$ Ada juga yang melihat citra perempuan dalam film. Suara perempuan memang mendapat tempat yang cukup memadai di beberapa sisi film ini. ${ }^{6}$ Ketika suara pria hening-senyap, suara perempuan justru lebih nyata menyaringkan kenyataan. "Kampung ini telah menjadi kampung orang munafik!" kata seorang perempuan dalam film tersebut.

Di luar semua telaah yang telah disebutkan itu, ada sisi yang juga patut dan menarik untuk dimasuki: film ini adalah film yang dengan berani mengungkapkan praktik seksualitas menyimpang dari sebuah masyarakat yang taat beragama, tidak hanya hiperseksualitas, homoseksualitas, tetapi juga lesbianitas. Untuk yang terakhir, misalnya, film ini telah dengan berani mempertontonkan perilaku erotis sesama wanita. Ben Murtagh $^{7}$ tentang ini misalnya menulis, "A brief but telling glimpse of same-sex erotic behaviour between women is to be found in Chaerul Umam's Titian serambut dibelah tujuh." Bahkan praktiknya sendiri, secara berani, dihadirkan dalam salah satu masyarakat yang [dianggap] religius di bumi Nusantara ini, yaitu masyarakat muslimMinangkabau.

Bagi masyarakat Minang, Islam merupakan keyakinan keagamaan yang merembes masuk ke dalam pengetahuan, perilaku, dan makna budaya. ${ }^{8}$ Menjadi muslim adalah orientasi

${ }^{5}$ Eric Sasono, "Muslim Sosial Dan Pembaharuan Islam Dalam Beberapa Film Indonesia",” 2011 Makalah untuk disampaikan pada diskusi di Komunitas Salihara, Eric Sasono, "Islamic Revivalism and Religious Piety in Indonesian Cinema," 2013, 45-75.

${ }^{6}$ Ben Murtagh, Genders and Sexualities in Indonesian Cinema: Constructing Gay, Lesbi and Waria Identities on Screen (London: Routledge, 2013).

${ }^{7}$ Ben Murtagh, "Lesbi in the Metropolis: Fatal Attraction in an Indonesian Movie from the Early 1990s," Review of Indonesian and Malaysian Affairs 45 (2011): 95-132.

${ }^{8}$ Dedi Arsa, "Kaum Komunis Dan Islam Reformis Dalam Roman-Roman Abdoelxarim M.S."," Jentera 8, no. 1 (2019): 26-47. 
terdalam dari identitas Minangkabau. ${ }^{9}$ Masyarakat tersebut taat pada Islam dan dalam waktu yang sama juga pengikut adat (tradisi) yang kuat. ${ }^{10}$ Orang-orang Minangkabau pada umumnya memeluk agama Islam. Umar Yunus, sebagaimana dikutip M. Junus Melalatoa, mengemukakan bahwa "kalau ada orang Minangkabau yang tidak menganut agama Islam, maka hal itu adalah suatu keganjilan yang mengherankan, walaupun seementara dari mereka mungkin menganut agama itu secara nominal saja, tanpa melakukan ibadahnya". Dalam keadaan biasa mereka boleh dikatakan tidak mengenal unsur-unsur kepercayaan lain, kecuali apa yang diajarkan oleh Islam. Sekalipun, dalam keadaan luar biasa banyak juga yang percaya pada hal-hal yang tidak diajarkan oleh Islam, misalnya percaya pada hantu-hantu yang mendatangkan bencana atau penyakit, minta bantuan pada dukun, percaya kepada kuntilanak. Namun dari waktu ke waktu pengamalan agama Islam itu semakin murni. ${ }^{11}$ "Adat basandi Syara' (Islam), Syara' basandi Kitabullah (Alquran)" telah lama menjadi identitas etnis suku Minangkabau. Ikrar yang dikenal dengan Piagam Buki Marapalam (kapan ikrar itu dibuat tidak diketahui dengan pasti, kemungkinan pasca-Padri).

Masuknya agama Islam ke Minangkabau memang tidak merombak semua nilai, pandangan dan prinsip hidup masyarakat. Pandangan dan nilai luhur kehidupan tetap dipelihara. Tetapi Islam memperkukuh nilai-nilai keminangkabauan itu. Alam takambang jadi guru, yang merupakan falsafah dasar orang Minangkabau, diperkuat oleh

${ }^{9}$ Lucy A Whalley, Meletakkan Islam Ke Dalam Praktik (Perkembangan Islam dalam Perspektif Gender Minangkabau", 1996) dalam ; Mark R Woodward, ed., "Jalan Baru Islam: Memetakan Paradigma Mutakhir Islam Indonesia" (Bandung: Mizan, 1996), 207.

${ }^{10} \mathrm{Jeffrey} \mathrm{Hadler,} \mathrm{Muslims} \mathrm{and} \mathrm{Matriarchs:} \mathrm{Cultural}$ Resilience in Indonesia Through Jihad and Colonialism (Ithaca and London: Cornell University Press, 2008); Tsuyoshi Kato, "Change and Continuity in the Minangkabau Matrilineal System"," Indonesia 25 (1978): 1-16.

${ }^{11}$ M.Junus Melalatoa, Ensiklopedi Suku Bangsa Di Indonesia (Jakarta: Departeman P \& K, 1995), 575-76. nila-nilai Islam: Kecendrungan dalam gejala alam dan hukum alam dan kehidupan manusia, oleh Islam dinamakan sunnatullah atau ayat-ayat Allah. $^{12}$ Sekalipun telah juga disinggung Muhammad Arief, ${ }^{13}$ yang melihat skenario film ini dalam relasinya dengan konteks Islam dan adatlokal, namun analisisnya tampak belum begitu menyentuh persoalan-persoalan seksualitas menyimpang secara lebih mendasar yang ditampilkan film ini di tataran masyarakat lokalmuslim tersebut. Orang-orang beragama, yang tata-hidupnya berlandaskan Islam, yang mengulang-ulang diktum "Adat Bersandi Syarak, Syarak Bersandi Kitab Allah", ${ }^{14}$ malah digambarkan film ini sebagai masyarakat yang penuh kemunafikan. Tokoh-tokoh dalam film ini mencerca perilaku sumbang-pergaulan, tetapi dalam perilaku keseharian malah memahfumi homoseksualitas dan lesbianitas dan 'melindungi' pemerkosa sehingga melenggang bebas. Sekalipun tampak menohok puak ini secara langsung, namun ketika film ini dirilis ke publik, baik ketika tahun 1950an maupun pada 1980an, tampaknya tak terdengar protes apa pun dari orang Minangkabau.

Untuk ini, menjadi menarik melihat bagaimana praktik-praktik seksualitas menyimpang digambarkan dalam film ini dan bagaimana konstruksi dalam film punya relasi

${ }^{12}$ Bustanuddin Agus, "Islam Dan Budaya Minang: Suatu Kebutuhan Dalam Menatap Masa Depan”" (Padang, 2004) (makalah) disampaikan dalam Seminar Internasional Kebudayaan: " Minangkabau dan Potensi Etnik dalam Paradigma Multikultural." Diselenggarakan oleh Program Studi Bahasa dan Sastra Minangkabau, Jurusan Sastra Daerah-Universitas Andalas, pada 23-24 Agustus 2004, di Inna Muara Hotel, Padang.

${ }^{13}$ Arief, "Analisis Konteks Islam Dan Budaya Minangkabau Dalam Skenario Film Titian Serambut Dibelah Tujuh"," 213-16.

${ }^{14}$ Tentang proses pengentalan informasi ini dalam masyarakat yang dimaksud cukup banyak yang bisa dirujuk diantaranya: Taufik Abdullah, "Adat and Islam: An Examination of Conflict in Minangkabau"," Indonesia, no. 2 (1966): 1-24 Lihat Juga: ; Alexander Stark, "The Matrilineal System of the Minangkabau and Its Persistence Throughout History: A Structural Perspective"," Southeast Asia: A Multidisciplinary Journal 13 (2013): 1-13. 
dengan konstruksi di luarnya baik pada aspek sosial maupun budaya dan mungkin juga politik ketika film ini diproduksi?

Dua pertanyaan pokok tersebut akan dijawab artikel ini menggunakan pendekatan neobistorisism, yang mula-mula diperkenalkan Stephen Greenblatt pada 1980an dan mendapat tempat yang luas di dasawarsa-dasawarsa setelahnya sebagai piranti untuk menahami karya sastra (termasuk film) melalui konteks sosial-politik dan budaya yang melahirkannya. Semua pengetahuan tidak pernah bebas dari anasir lain, senantiasa terkontaminasi. Dalam historisisme baru ini karya sastra (film) dianggap mempunyai hubungan dengan pandangan-pandangan penulisnya sendiri (episteme pengarang) dan pandangan-pandangan zamannya (tradisi, sosiologi, agama, politik, dan wacana-wacana budaya lain) yang saling bersaing dan berkelindan dengan kompleks. ${ }^{15}$

Dalam hubungannya dengan sejarah, karya sastra (film) adalah produk sejarah, tetapi sekaligus juga produsen sejarah; teks sastra menggambarkan situasi sejarah sekaligus merespons situasi sejarah. ${ }^{16}$ Dengan begitu, artikel ini mengkaji perspektik kesejarahan, baik budaya, politik, maupun sosial dalam teks sastra (film); dan memahami sastra (film) melalui latar masyarakat yang memproduksinya. Dengan kata lain, artikel ini hendak mencari keterhubungan antara karya sastra (film) dalam konteks ruang dan waktu (sejarah).

Untuk mendapatkan gambaran yang demikian atas film ini, akan dilakukan dua model analisis: prosesual dan struktural. Analisis prosesual $^{17}$ digunakan guna menyusun alur film

${ }^{15}$ Andri Wicaksono, "Sejarah Politik Indonesia Dalam Novel Larasati Karya Pramoedya Ananta Toer"," Jentera 7, no. 1 (2018): 24; Robin Headlam Wells dkk, NeoHistoricism: Studies in Renaissance Literature, History, and Politics (Cambridge: D.S. Brewer, 2000).

16Raman Selden and Peter Widdowson, A Reader's Guide to Contemporary Literary Theory (The University Press of Kentucky, 1993).

${ }^{17} \mathrm{G} \mathrm{J}$ Garaghan, A Guide to Historical Method (New York: Fordham University Press, 1984). yang dimaksud. Sementara itu, analisis struktural ${ }^{18}$ digunakan untuk menganalisis pandangan karyakarya tersebut dalam mencitrakan atau merepresentasikan praktik seksualitas menyimpang. Pada tahap analisis struktural akan dilihat makna teks melalui (1) interpretasi atas teks yang berupa pencarian ide utama; pandanganpandangan pengarang melalui narasi-narasi dominan; dan narasi-narasi yang dimenangkan melalui perkembangan dan perubahan karakter tokoh utama, termasuk masyarakat yang menyuarakan pendapatnya atau tokoh-tokoh pendukung dan (2) interpretasi atas sosio-budaya sebagai latar penciptaan teks, baik latar teks yang dihasilkan maupun latar dalam teks itu sendiri dan tentu saja mencakup latar sosio-budaya pengarangnya.

\section{PRAKTIK-PRAKTIK SEKSUALITAS DALAM FILM}

Bagian ini mengelaborasi beberapa praktik seksualitas menyimpang yang digambarkan dalam film ini, berupa homoseksualitas, lesbianitas, dan hiperseksualitas (lewat praktik perkosaan). Lalu pada bagian ini juga digambarkan konteks sosial-budaya latar film (yang juga menjadi masyarakat asal dari pengarang/penulis skenario) serta latar sosialbudaya ketika film ini diproduksi, dan yang terakhir juga dianalisis diskursus yang dimenangkan pengarang sebagai representasi pandangan pengarangnya sendiri.

Film ini bercerita tentang seorang guru, Ibrahim, yang ingin mengubah sebuah kampung, tetapi mesti berhadapan dengan rintangan ketidaksukaan masyarakat. Sang Guru, yang diperankan El Manik, yang baru saja lulus sekolah guru agama dan mendapat panggilan tugas untuk mengabdi sebagai guru mengaji di sebuah kampung terpelosok.

Berlatar sebuah kampung di Minangkabau, negeri matriarkat dan terkenal sebagai pusat

${ }^{18}$ Sartono Kartodirdjo, Pendekatan Ilmu Sosial Dalam Metodologi (Jakarta: Gramedia, 1993). 
kesalehan. Kampung itu, disebut dalam film, bernama Tanjung Beringin, memang terlihat terisolir dari kemajuan: jalanannya belum diaspal dan orang-orang kaya di kampung itu pun masih berjalan jauh dengan bendi dan pedati. Rumahrumah penduduk masih rumah panggung tradisional bergaya pesisir Minangkabau (bukan rumah gadang khas pedalamannya yang bergonjong), tanpa ada rumah gedung dengan beton. Bebiasaan masyarakatnya yang menjadikan kedai/lepau/warung kopi sebagai episentrum pergaulan kaum laki-laki menunjukkan kebiasaan umum masyarakat kebudayaan ini. Ada masjid yang menjadi pusat bagi aktifitas beragama, juga ada balai adat tempat problematika kampung itu dibicarakan dalam sidang atau rapat.

Masyarakat yang digambarkan film ini adalah masyarakat agrikultur yang mengandalkan penghidupan ekonomi dari pertanian hasil hutan. Mereka menjadikan sungai sebagai tempat untuk membersihkan diri dan mencuci. Lingkungan alamnya masih didominasi pepohonan rimbun dan lebat di mana-mana dan lanskapnya sering diselimuti kabut. Tampaknya modernitas belum hadir begitu jauh di sini. Motor, misalnya, di kampung ini adalah sebentuk kemewahan elite, pemiliknya adalah seorang rente, yang memperanak uang, tetapi menyumbang banyak untuk pembangunan masjid. Saban hari, motor itu meraung-raung ke penjuru kampung, sekaligus menebarkan ketakukan. Sebab sang rente, Arsyad, adalah juga pemburu gadis-gadis sekalipun telah punya istri dan anak-anak.

1. Arsyad merepresentasikan tokoh dengan gangguan seksual yang ini: 'hiperseksual'. Dia memiliki istri dan beberapa anak yang 'bersusun pagi' (jarak umur antara anak-anak itu dekat). Tetapi dia justru terlibat dalam perburuan liar yang menggiurkan terhadap perempuan-perempuan lain. Dia setidaktidaknya dalam film itu telah melakukan pemerkosaan sebanyak tiga kali, dua kali terhadap Halimah dan yang ketiga terhadap tokoh perempuan lain yang tidak disebutkan namanya. Pada perkosaan yang pertama, Arsyad melenggang bebas, sedang korbannya (Halimah) dilara trauma yang berkepanjangan kemudian dan hidup sebagai gadis gila yang menjadi cibiran seluruh kampung karena telah ternoda. Percobaan terhadap Halimah dilakukannya lagi, ketika 'gadis gila' itu sedang mandi di sungai, Arsyad membuntutinya, mengintainya, dan ketika lengah menghempaskannya ke semak-semak di jalan setapak menuju sungai itu, menggerayanginya, menindihnya, mencoba untuk memperkosanya. Halimah melawan, dia mencakar muka Arsyad. Di saat yang bersamaan, kejadian itu dipergoki Guru Ibrahim dan adik Halimah yang kebetulan lewat di dekan situ. Mengetahui itu Arsyad terpaksa melarikan diri sambil memegangi mukanya yang terluka dan usahanya yang kali kedua ini pun gagal sudah. Tapi anehnya, Arsyad sendirilah yang kemudian mengadukan atau membawa kejadian itu ke dalam sidang atau rapat di masjid yang dihadiri pada elite-elite kampung itu. Arsyad menuntut Halimah karena telah mencelakai dia dan meminta kepada hadirian untuk mengusir atau memasung gadis gila itu agar tidak membuat malu kampung itu atau mencelakai orang lain lagi. "Arsyad, coba ceritakan apa yang terjadi?" kata seorang anggota rapat memulai. Arsyad mengarang ceritanya sendiri yang sama sekali berbeda dengan apa yang telah terjadi. Selengkapnya:

$$
\text { ARSYAD: }
$$

Saya berpapasan dengan dia (Halimah) tadi siang. Seperti biasanya, saya suruh dia pulang. Eh, tiba-tiba dia menyerang saya, habis muka saya dicakarnya. Ini bekasnya masih kelihatan (sembari menunjukkan bekas cakaran pada pipinya yang sebelah kiri kepada sidang yang berhadir). Betul juga apa yang dikatakan Bapak Guru Besar kita, Bapak Sulaiman, kalau dalam diri gadis itu 
telah bersarang iblis. Kelihatannya orangtuanya sendiri sudah tidak mampu lagi menahannya di rumah. Saya betul-betul khawatir nasib kampung kita. Malu rasanya jika bertemu dengan orang kampung lain.

“Apakah ada yang melihat kejadian itu?” tanya anggota rapat yang terlihat menyangsikan keterangan Arsyad. Arsyad dengan lihat menuding dan melemparkan tuduhan pada Guru Ibrahim dan sekaligus menebarkan ancaman untuk menjahatinya. Selengkapnya:

$$
\text { ARSYAD: }
$$

Guru Ibrahim. Tapi saya curiga pada guru itu. Saya lihat dia sering ke rumah perempuan itu. Ini kan sama saja dengan menginjak-injak kepala kita. Waktu dia datang, saya lari. Saya takut dia salah paham.

GURU SULAIMAN:

Nanti saya periksa.

$$
\text { ARSYAD: }
$$

Tolonglah, kalau masih bisa. Jangan sampai tangan kami ini terlanjut mengenai dia.

Sementara pada percobaan perkosaan yang dilakukannya untuk kali ketiga, dijalankannya kepada perempuan lain yang tidak disebutkan namanya dalam film itu. Hanya saja kali ini Arsyad tertimpa sial, dan kesialan itu mengakhiri petualangannya, sekaligus menyudahkan hidupnya. Tiga orang peladang memergokinya tengah memperkosa seorang perempuan di semak-semak, lalu menyoraki dan mengejarnya. Arsyad masih sempat melarikan diri ke rumahnya dan berpura-pura tidur. Tetapi orang-orang kampung yang sudah semakin banyak berkumpul untuk memburunya, menggedor rumahnya, dengan kelewang di tangan masing-masing menuntut hukuman bagi si pemerkosa. Mengetahui itu Arsyad melarikan diri lagi, menaiki motornya, tetapi terjatuh dan mati.

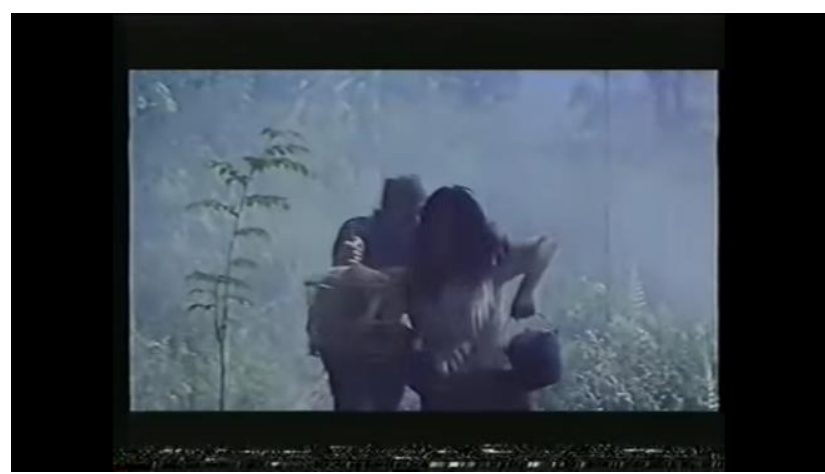

Adegan 1: Arsyad sedang berusaha memperkosa

Halimah.

2. Tokoh antagonis lain, Harun, kaya oleh judi, tapi memelihara seorang anak jawi, yang menjadi pengasuh kuda dan perawat bendinya. Tokoh kita yang ini merepresentasikan tokoh dengan gangguan seksual yang ini: 'homoseksual'. Hidup dalam kubangan harta, punya istri yang padat-berisi, montok lagi cantik-menggairahkan, tapi menumpahkan hasrat justru pada sesama lelaki. Perawat kuda \& bendinya, Ukan, memiliki tubuh kurus lagi kerempeng tetapi agak terlihat kemayu pada gerak, merepresentasikan pasangan laki-lakinya, yang bisa bertingkah manja di hadapan tuannya, dan diperlakukan sama manjanya oleh sang tuan. Pada satu adegan, sang tuan sedang duduk di atas buayan. Ukan tampak bergerak mengelilingi si tuan dengan sikapnya yang manja. Mereka berdua saling menggoda di atas buayan yang terus bergoyang di samping rumah panggung. Diselingi cekikan menggoda antara keduanya, dan tingkahan rebana dari Ukan, mereka bergelut bagai menampilkan adekan percintaan di rancang. Harun mengelus-ngelus pantat Ukan, sementara Ukan menghamparkan kepalanya di selangkangan Harun. 


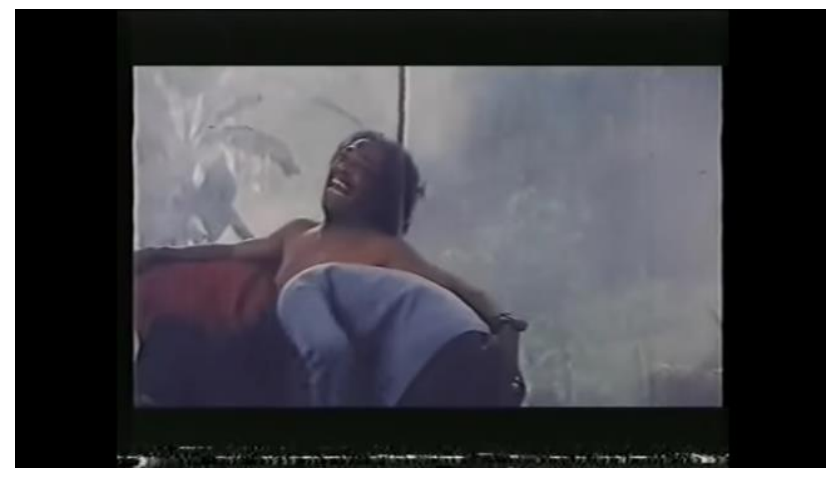

Adegan 2: Harun dan Ukan sedang ber'gelut' di atas buayan.

3. Sementara istri Harun (Leha), yang barangkali tak puas dengan kehidupan seksual bersama suaminya yang asyik dan sibuk dengan kekasih sesama jenisnya, tergiring ke penyimpangan baru dengan pembantu perempuannya. Tokoh kita yang ini merepresentasikan tokoh dengan gangguan seksual yang ini: 'lesbianitas'. Di atas rumah gadang, di atas kursi goyang, Lela meminta pembantunya Iyah mengelus kepalanya yang sakit. Tapi tidak sekadar memijit bagian kepala, tangan pembantunya itu digamparkan terus turun menyisir ke bagian leher dan terus lebih jauh ke pangkal dada bagian atasnya. Elusan-elusan berhasrat Iyah pada bagianbagian sensitif itu membuat si nyonya larut dalam hasrat, begitu juga si pembantu perempuan itu tampak memicingkan mata dengan nafas yang berat, larut dalam arus nafsu yang sama, terengah-engah. Adegan kemudian memang dipindahkan dengan cepat, tetapi kita tahu itu adalah sebuah adegan percintaan 'liar' sesama jenis antara nyonya dan pembantu perempuannya.

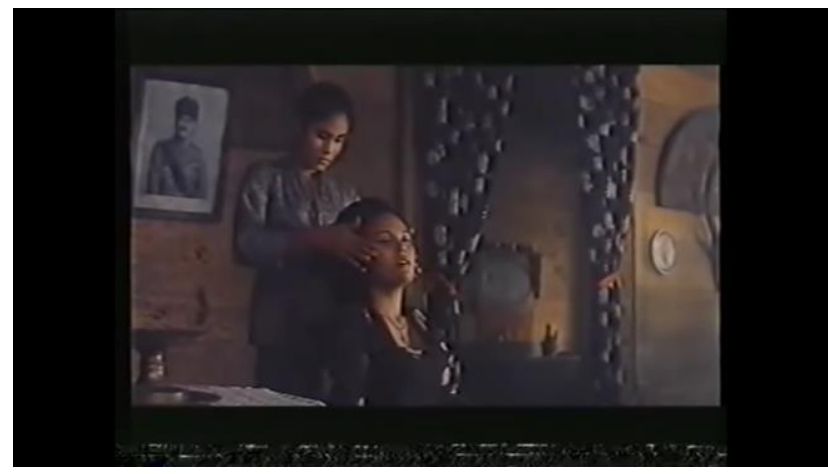

Adegan 3: Lela dan Iyah sedang ber'cengkerama' di atas kursi goyang.

\section{LATAR SOSIAL-BUDAYA DALAM FILM: PENYIMPANGAN SEKSUAL DALAM REALITAS SOSIAL-BUDAYA MASYARAKAT MINANGKABAU}

“Tembakkan meriammu, Harun!" kata orang-orang di kedai kopi, ketika pasangan tokoh antagonis itu, Ukan, tampak berbaring sambil menunggingkan pantat. Apakah arti 'meriam' dalam konteks itu? Masyarakat dalam film itu tampaknya telah mahfum akan praktik yang mereka, sepasang laki-laki itu, lakukan. Bahkan dalam sebuah rapat yang berlangsung di masjid, Ukan dengan mesra tidur di atas paha Harun sambil memainkan rebana, di hadapan Haji Sulaiman dan para peserta rapat yang lain. Sementara rapat itu sendiri membicarakan soal moralitas: Pak Guru Ibrahim yang sering bertandang ke rumah Halimah sebagai suatu perilaku sumbang. Maka betul juga apa yang telah dikutip di atas, "Kampung ini telah menjadi kampung orang munafik!"

Sebagaimana tadi ditulis, latar film ini adalah Tanjung Beringin, kampung terisolir penghasil karet di Minangkabau. Jelas bukan Tanjung Beringin dalam realitas, tetapi nagari fiktif-rekaan belaka si penulis skenario. Tetapi dari karakteristik masyarakat yang ditampilkannya, itu merujuk sebuah kampung di Minangkabau: kebiasaan kaum laki-laki yang menjadikan lepau kopi sebagai epistentrum aktifitas sosial; tepian tempat mandi sebagai pusat bagi aktifitas bersih badan dan pakaian; termasuk cara berpakaian 
kaum laki-laki dan perempuan di kampung itu. Bagi Eric Sasono, problem seksualitas yang ada dalam film itu diambil dari khazanah masyarakat lain. "Problem sexualitas itu bisa jadi diambil dari kisah Sodom dan Gomorrah," kata Eric menyinggung sisi seksualitas menyimpang dalam film ini. ${ }^{19}$ Tapi pendapat itu tidak sepenuhnya memadai, karena tidak punya relasi yang tepat dengan penulis skenarionya sendiri. Film ini justru lebih dekat menggambarkan masyarakat latarnya, dan masyarakat dari mana si penulis skenarionya berasal (Minangkabau) alih-alih sebuah dunia lain yang jauh.

Homoseksual sendiri punya jejaknya sendiri dalam masyarakat Minangkabau. Bahasa lokal untuk praktik itu adalah 'anak jawi'. Kata orang, istilah itu hasil dari usaha orang Minangkabau berguru ke alam, seperti diktumnya yang terkenal, "Alam Terkembang Jadi Guru". Lihatlah bagaimana anak jawi (sapi) berperilaku, suka mengendus-ngendus ekor induknya. Ada juga pendapat yang mengatakan, istilah itu berasal dari perilaku buruh-buruh di lubang-lubang tambang di Sawahlunto, yang karena tidak disediakan perempuan oleh perusahaan, jadi memangsa sesama buruh yang lebih muda. Kebanyakan buruh-buruh itu didatangkan perusahaan dari Jawa-jawi. ${ }^{20}$

Praktik itu sendiri, selain di kalangan buruh tambang, di antaranya, banyak juga berlangsung di tengah aktifitas laki-laki Minangkabau yang secara tradisi tidur dan beraktifitas di surau; praktik ini juga banyak terjadi di kalangan sais pedati dan kusir bendi. Untuk yang disebutkan terakhir, seperti kata penyair Rusli, "Tabiat kusir bendi dikonotasikan buruk, tidur di kandang kuda, tidak jarang mempekerjakan stokar, anak-anak atau remaja lakilaki yang bertugas membantu si kusir menyabit

${ }^{19}$ Sasono, "Muslim Sosial Dan Pembaharuan Islam Dalam Beberapa Film Indonesia"."

${ }^{20}$ Erwiza Erman, Miners, Managers and the State: A Socio-Political History of the Ombilin Coal-Mines, West Sumatra, 1892-1996" (Disertasi, Universiteit van Amsterdam, 1999). rumput dan memandikan kuda-tetapi kadang sekaligus jadi anak jawi." ${ }^{21}$ Dalam film ini, hubungan yang lebih-kurang mirip dengan itulah yang berlangsung, antara pemilik bendi (Harun) dengan tukang urus kudanya (Ukan).

Lalu bagaimana dengan yang lesbianitas dan hiperseksualitas? Memang diakui tidak ada data (historis) yang memadai untuk merekonstruksi dua praktik di atas. Hanya dapat dikatakan secara serba sedikit kalau istilah 'lesbian' baru pertama kali digunakan sejak 1990an. Dari data-data sementara, Sumatra Barat (tempat etnis Minangkabau bermukim) menjadi daerah dengan angka lesbian terbanyak di Indonesia pada sekira satu dasawarsa belakangan. ${ }^{22}$ Pada 2013-2015, misalnya, jumlah lesbian tercacat meningkat di Padang, kota utama kawasan ini. ${ }^{23}$ Data-data kuantitatif yang dikutip ini juga tidak memberi kejelasan seberapa dominan pelakunya adalah orang Minangkabau, akan ada kemungkinan bahwa data-data itu merangkum berdasarkan domisili belaka bukan berdasarkan suku bangsa. Perlu juga dipertingkan di sini kalau kota utama Sumatra Barat itu sudah cukup homogen sejak lama, di mana di sana bermukim begitu banyak suku bangsa sekalipun tetap yang paling dominan adalah Minangkabau. Lesbianitas sendiri mungkin ada terjadi dalam realitas masyarakat ini di masa lalu yang lebih awal, tapi tidak pernah menjadi perhatian mengingat perempuan lebih banyak beraktifitas di ruang privat, berbeda dengan homoseksualitas di mana pelakunya aktif di ruangruang publik.

${ }^{21}$ Fikrul Hanif Sufyan and Dedi Arsa, "Kuda Bendi Di Kota Payakumbuh Sumatera Barat Sampai Akhir Abad Ke-20"," Mozaik Humaniora 17, no. 1 (2017): 45-71.

${ }^{22}$ Gema Pertiwi and Yusril, "Penciptaan Film Fiksi Siriah Jadi Karakok Dengan Fenomena Lesbian Di Sumatera Barat, Gorga: Jurnal Seni Rupa," 2019 Film fiksi Siriak jadi Karakok sendiri adalah hasil karya dari sineas Minangkabau yang menjadikan fenomena lesbian di kawasan itu sebagai objek material untuk menghasilkan karya.

${ }^{23}$ Angka-angka digit mengenai ini lihat di antaranya: Afrino Reki, "Studi Fenomenologi: Konsep Diri Homoseksual (Lesbian) Di Kota Padang,” 2016. 
Sementara untuk kasus perkosaan, beritaberita di koran kuning masa kini memberikan gambaran yang bisa jadi cukup memadai tentang perkembangannya di masa kini. Tapi, untuk merelasikannya dengan konteks penelitian ini (secara historis) tidaklah terlalu tepat mengingat temporalnya telah sama sekali jauh berjarak. Kita mesti melacak ke masa-masa yang lebih awal, sesuai dengan ruang-waktu skenario film ini diproduksi. Tapi sayangnya, sebagaimana tadi telah diakui juga diakui tidak terdapat data (historis) yang memadai Data-data resmi mengenai ini jelas akan sulit didapatkan. Tetapi, karya-karya sastra bisa jadi telah menjadi corong yang terbuka untuk menyuarakan apa yang tidak disuarakan saluran-saluran umum masyarakat. Apa kita perlu melacak karya-karya sastra yang sezaman dengan ini? Beberapa pengarang prosa yang melakukan kerja kreatif pada kurun ini yang paling menonjol di antaranya adalah karya A.A. Navis, Soewardi Idris, dan Gus tf Sakai di antaranya yang menyinggung kasus-kasus perkosaan pada masa-masa chaos (perang). ${ }^{24}$ Saya pikir setiap masyarakat tidak pernah steril dari kejahatan pemaksaan kehendak semacam perkosaan, jadi hal ini telah jadi sesuatu yang melekat belaka termasuk pada masyarakat Minangkabau.

\section{LATAR SOSIAL-BUDAYA KETIKA DIPRODUKSI: KRITIK ATAS DEKADENSI MORAL ORDE LAMA DAN ORDE BARU}

Kurun di mana seseorang hidup sangat penting untuk memahami sikap-sikap dan tindakannya, juga pikiran-pikirannya, termasuk

${ }^{24}$ Dedi Arsa, "Padangan Karya-Karya Fiksi Atas Nasib Perempuan Minangkabau Korban Pemberontakan Daerah/PRRI 1958-1961"," Humanisma: Journal of Gender Studies 1, no. 2 (2011): 1-12 karya sejarah tentang topik yang sama dalam periode ini lihat ; Reni Nuryanti, "Perempuan, Seks, Dan Perang: Analisis Dalam Pergolakan Pemerintah Revolusioner Republik Indonesia (PRRI) (1958-1961)"," in Proceedings (Padang: BPSNT Padang Press dan Fakultas Sastra Unand, 2011). yang kemudian tertuang dalam karya-karyanya. Seseorang yang hidup dalam langit lazuardi sejarah tidak bisa tidak mesti terikat pada ruang dan waktu historisnya, begitu kata Popper. ${ }^{25}$ Untuk itu, perlu jugamelihat semangat zaman yang mendasari film yang dibahas ini untuk dapat memahami motivasi pengarangnya secara lebih baik.

Eric Sasono mengatakan kalau film ini hadir untuk menohok Orde Baru. Film ini hadir pada puncak kemakmuran Orde Baru, dan sebagai karya sastra, ia adalah cerminan realitas, jadi, ia merepresentasikan realitas moral Orde Baru, demikian yang dimaksud si peneliti. Selengkapnya Eric Sasono ${ }^{26}$ menulis:

Asrul mencoba meningkatkan penggunaan alusi dan metafor dalam film ini untuk menggambarkan negara Orde Baru ... alusi yang paling penting justru adalah dekadensi moral negara Orde Baru itu sendiri dalam keseluruhan film ini.

Tapi jika memperhatikan tahun pembuatannya, skenario film ini tampak telah jauh-jauh tahun ditulis dan diselesaikan Asrul Sani, bahkan seperti yang dicatat di atas, pernah difilmkan juga sebelumnya pada 1950an. Menimbang hal itu, lebih tepat disebut, kalau film ini cerminan dari jiwa zamanya. Justru film ini adalah kritikan atas dekadensi moral Orde Lama (alih-alih Orde Baru seperti yang disebut Eric di atas) ketika Soekarno merayakan binalitas di ruang publik dengan wanita penghibur dari Jepang dan artis terkenal dari Amerika. Pada kurun ini pula, ketika Nasionalis, Komunis, dan Agama hendak disatukan dalam satu konsep doktrinal Nasakom, di masyarakat nilai-nilai moral dan agama justru tengah mengalami degradasi yang sama.

${ }^{25}$ Karl Popper, The Open Society and Its Enemies (Princeton: Princeton UP, 1971); Arsa, "Kaum Komunis Dan Islam Reformis Dalam Roman-Roman Abdoelxarim M.S.,", 28-29.

${ }^{26}$ Sasono, "Muslim Sosial Dan Pembaharuan Islam Dalam Beberapa Film Indonesia"." 


\section{RELASINYA DENGAN PENGARANG: SI(APA) YANG AKHIRNYA DIMENANGKAN?}

Tak ada 'Negara' dalam film ini. Tak ada polisi, tidak ada aparat nagari, tidak ada tandatanda kehadiran pemerintah dalam berbagai bentuknya. Masyarakat itu semata-mata dikuasai orang kaya (Harun \& Arsyad) yang menguasai kalangan agama (Haji Sulaiman) dan kalangan tradisional (elite-elite kampung); kedua kalangan itu tak mampu berkata-kata karena disiram uang oleh yang pertama. Akibatnya, hukum yang berlaku adalah hukum rimba, rakyat banyak adalah hakim dalam setiap peristiwa: peristiwa pengusiran Halimah, tuduhan perkosaan yang menimpa Ibrahim, dan penangkapan Arsyad. "Rakyat di kampung itu seperti layang-layang putus!" kata seorang ustad bijaksana yang hadir di awal dan di akhir-yang menyingkir dari kampung itu di awal tapi kemudian datang lagi di akhir. Di sini tampak siapa yang hendak dimenangkan Asrul Sani. Di satu sisi, negara yang mesti hadir untuk mengatur (ketiadaan negara menyebabkan kekacauan rakyat); dan di sisi lain, agama yang harus ada sebagai acuan, tanpa panduan agama rakyat diterbangkan keadaan tak tentu arah, termasuk merayakan perilaku seks menyimpang.

Seperti telah disinggung di awal, Asrul Sani berasal dari utara Minangkabau, dari Rao, yang pernah menjadi ketua lembaga kebudayaan milik NU (Nahdhatul Ulama), Lesbumi (Lembaga Seniman Budayawan Muslimin Indonesia) pada masa Orde Lama. Pada masa ini pulalah skenario ini ditulisnya. Untuk itu, skenario untuk film ini, dapat dikatakan, adalah salah satu bentuk 'pertanggungjawaban' darinya sebagai Muslim dan sebagai anggota sebuah lembaga kebudayaan dari sayap sebuah partai Muslim ketika itu.

Asrul Sani, dalam film ini, memenangkan sebuah diskursus bahwa agama adalah sesuatu yang mesti ada dalam kehidupan manusia sebagaimana harus adanya negara. Apakah ini sebuah 'serangan' tidak langsung atas komunisme yang ingin menirkan agama dalam masyarakat mengingat konfrontasi yang memang tengah memanas di antara kedua golongan ini pada masa itu di mana Asrul sendiri adalah wakil dari yang disebutkan terakhir? Bisa saja memang demikianlah adanya, tapi artikel ini telah jadi terlalu jauh jika harus membicarakannya pula.

\section{PENUTUP}

Titian Serambut Dibelah Tujuh karya Asrul Sani mengetengahkan beberapa praktik seksualitas menyimpang: homoseksualitas, lesbianitas, dan hiperseksualitas (lewat praktik perkosaan). Narasinarasi dalam film ini terkait dengan konteks kehadirannya di tengah realitas sosial Indonesia: film ini hadir sebagai kritik atas dekadensi moral Orde Lama yang merayakan banalitas-seksualitas di ruang publik. Di sisi lain, film ini juga menggambarkan masyarakat latar dari mana si penulis skenarionya berasal: Minangkabau. Di tengah masyarakat ini, praktik-praktik seksualitas menyimpang punya jejaknya tersendiri. Praktikpraktik itu terjadi baik di lingkungan pergaulan surau, lubang tambang, hingga di kehidupan sehari-hari pada sais pedati dan bendi (delman).

Film ini memenangkan agama sebagai acuan hidup, di mana tanpa itu orang-orang akan diterbangkan keadaan tak tentu arah, termasuk merayakan perilaku seks menyimpang. Pesan ini sendiri sejalan dengan pesan Islam di mana penulis skenario film ini bernaung, sebagai bentuk 'pertanggungjawaban' darinya sebagai Muslim dan sebagai anggota sebuah lembaga kebudayaan dari sayap sebuah partai Muslim. Selain itu, pesan film ini sesuai pula dengan kondisi sosial-budaya ketika film ini diproduksi, yaitu saat dekadensi moral Orde Lama tengah mendapat perayaan di ruangruang publik.

\section{DAFTAR KEPUSTAKAAN}

Abdullah, Taufik. "Adat and Islam: An Examination of Conflict in Minangkabau"." 
Indonesia, no. 2 (1966).

Agus, Bustanuddin. "Islam Dan Budaya Minang: Suatu Kebutuhan Dalam Menatap Masa Depan”." Padang, 2004.

Anwar, Rosihan. "Asrul Sani Pribadi Religius." Republika, 2004.

Arief, Muhammad. “Analisis Konteks Islam Dan Budaya Minangkabau Dalam Skenario Film Titian Serambut Dibelah Tujuh"." Menara Ilmu X, no. 73 (2016): 213-216.

Arsa, Dedi. "Kaum Komunis Dan Islam Reformis Dalam Roman-Roman Abdoelxarim M.S.".” Jentera 8, no. 1 (2019): 28-29.

. "Padangan Karya-Karya Fiksi Atas Nasib Perempuan Minangkabau Korban Pemberontakan Daerah/PRRI 1958-1961".” Humanisma: Journal of Gender Studies 1, no. 2 (2011): 1-12.

dkk, Robin Headlam Wells. Neo-Historicism: Studies in Renaissance Literature, History, and Politics. Cambridge: D.S. Brewer, 2000.

Erman, Erwiza. Miners, Managers and the State: A Socio-Political History of the Ombilin Coal-Mines, West Sumatra, 1892-1996". Disertasi, Universiteit van Amsterdam, 1999.

Garaghan, G J. A Guide to Historical Method. New York: Fordham University Press, 1984.

Hadler, Jeffrey. Muslims and Matriarchs: Cultural Resilience in Indonesia Through Jibad and Colonialism. Ithaca and London: Cornell University Press, 2008.

Huda, Ahmad Nuril. "Negotiating Islam with Cinema: A Theoretical Discussion on Indonesian Islamic Films, Wacana: Jurnal Ilmu Pengetahuan Budaya," 2012.

Kartodirdjo, Sartono. Pendekatan Ilmu Sosial Dalam Metodologi. Jakarta: Gramedia, 1993.

Kato, Tsuyoshi. "Change and Continuity in the Minangkabau Matrilineal System"." Indonesia 25 (1978): 1-16.

Melalatoa, M.Junus. Ensiklopedi Suku Bangsa Di Indonesia. Jakarta: Departeman P \& K, 1995.
Murtagh, Ben. Genders and Sexualities in Indonesian Cinema: Constructing Gay, Lesbi and Waria Identities on Screen. London: Routledge, 2013.

-. "Lesbi in the Metropolis: Fatal Attraction in an Indonesian Movie from the Early 1990s." Review of Indonesian and Malaysian Affairs 45 (2011).

Nuryanti, Reni. "Perempuan, Seks, Dan Perang: Analisis Dalam Pergolakan Pemerintah Revolusioner Republik Indonesia (PRRI) (1958-1961)"." In Proceedings. Padang: BPSNT Padang Press dan Fakultas Sastra Unand, 2011.

Pertiwi, Gema, and Yusril. "Penciptaan Film Fiksi Siriah Jadi Karakok Dengan Fenomena Lesbian Di Sumatera Barat, Gorga: Jurnal Seni Rupa," 2019.

Popper, Karl. The Open Society and Its Enemies. Princeton: Princeton UP, 1971.

Rampan, Korrie Layun. Leksikon Susastra Indonesia. Jakarta: Balai Pustaka, 2000.

Reki, Afrino. "Studi Fenomenologi: Konsep Diri Homoseksual (Lesbian) Di Kota Padang," 2016.

Rosidi, Ajip. Mengenang Hidup Orang Lain: Sejumlab Obituari. Jakarta: Kepustakaan Populer Gramedia, 2010.

Sasono, Eric. "Islamic Revivalism and Religious Piety in Indonesian Cinema," 2013.

Dalam Beberapa Film Indonesia"," 2011.

Selden, Raman, and Peter Widdowson. A Reader's Guide to Contemporary Literary Theory. The University Press of Kentucky, 1993.

Stark, Alexander. "The Matrilineal System of the Minangkabau and Its Persistence Throughout History: A Structural Perspective"." Southeast Asia: A Multidisciplinary Journal 13 (2013): 1-13.

Sufyan, Fikrul Hanif, and Dedi Arsa. "Kuda

Bendi Di Kota Payakumbuh Sumatera Barat Sampai Akhir Abad Ke-20"." Mozaike Humaniora 17, no. 1 (2017). 
Sugono, Dendy, ed. "Ensiklopedia Sastra Indonesia Modern.” In Pusat Bahasa, 45-48. Jaka: Pusat Bahasa, 2003.

Whalley, Lucy A. Meletakkan Islam Ke Dalam Praktik. Perkembangan Islam dalam Perspektif Gender Minangkabau”, 1996.

Wicaksono, Andri. "Sejarah Politik Indonesia Dalam Novel Larasati Karya Pramoedya Ananta Toer"." Jentera 7, no. 1 (2018).

Woodward, Mark R, ed. "Jalan Baru Islam: Memetakan Paradigma Mutakhir Islam Indonesia," 207. Bandung: Mizan, 1996. 